\title{
The Correlation between Position and Duration Use of Laptops with Musculoskeletal Disorders (MSDs)
}

Korelasi Posisi dan Durasi Penggunaan Laptop dengan Muskuloskeletal Disorders (MSDs)

\author{
Raden Ayu Tanzila ${ }^{1 *}$, Thia Prameswarie ${ }^{2}$, Miranti Dwi Hartanti ${ }^{3}$, Talitha Denaneer ${ }^{4}$ \\ ${ }^{1}$ Department of Physiology, Faculty of Medicine, Universitas Muhammadiyah Palembang \\ 2 Department of Parasitology, Faculty of Medicine, Universitas Muhammadiyah Palembang \\ ${ }^{3}$ Department of Pharmacology, Faculty of Medicine, Universitas Muhammadiyah Palembang \\ ${ }^{4}$ Faculty of Medicine, Universitas Muhammadiyah Palembang
}

DATA OF ARTICLE:

Received: 25 Mar 2021

Reviewed: 25 May 2021

Revised: 02 July 2021

Accepted: 07 July 2021

*CORRESPONDENCE:

ratanzila247@gmail.com

DOI:

10.18196/mmjkk.v21i2.11375

TYPE OF ARTICLE:

Research

\begin{abstract}
The pandemic period forces all learning processes to be carried out online by utilizing internet facilities with a laptop. The position of using a laptop that is not ergonomic can cause musculoskeletal disorder. This study aims to determine the correlation between position and duration of student use of laptops during online learning with Musculoskeletal Disorders (MSDs). This research is analytic observational with a cross-sectional approach. The research was conducted on active students of the Medical Study Program, Muhammadiyah Palembang University, with 416 respondents. Primary data collection was taken using a questionnaire with a Nordic Body Map score. The analysis technique used the ChiSquare test. The results showed that the respondents had a high duration of laptop use (48.8\%), with a not good position (42.3\%). Most musculoskeletal disorders were felt in the neck $(75.5 \%)$. There was a correlation between the position of using a laptop and musculoskeletal disorders ( $\mathrm{p}$ 0.652). However, there was no correlation between the duration of laptop use and musculoskeletal disorders ( $\mathrm{p}$ 0.002). It can be concluded that the position of using a laptop that is not ergonomic caused musculoskeletal disorders.
\end{abstract}

Keywords: ergonomic; muskuloskeletal disorders; pandemic; online learning

Abstrak: Masa pandemi memaksa semua proses pembelajaran dilakukan secara daring memanfaatkan fasiltas internet dengan media laptop. Posisi penggunaan laptop yang tidak ergonomis dapat menyebabkan muskuloskeletal disorder. Penelitian ini bertujuan untuk mengetahui hubungan posisi dan durasi penggunaan laptop pada mahasiswa dengan keluhan muskuloskeletal. Jenis penelitian ini adalah observasional analitik dengan pendekatan cross sectional. Penelitian dilakukan pada mahasiswa aktif Program Studi Kedokteran Universitas Muhammadiyah Palembang dengan total sampel sebanyak 416 responden. Pengumpulan data primer diambil dengan menggunakan kuesioner Nordic Body Map. Teknik analisis dengan menggunakan uji Chi-Square. Hasil penelitian didapatkan responden menggunakan laptop dengan durasi tinggi (48,8\%), posisi tidak baik (42,3\%), keluhan musculoskeletal paling banyak dirasakan pada daerah leher (75,5\%). Terdapat hubungan posisi penggunaan laptop dengan keluhan musculoskeletal $(p 0,652)$ dan tidak terdapat hubungan durasi penggunaan laptop dengan keluhan musculoskeletal (p 0,002). Dapat disimpulkan bahwa posisi penggunaan laptop yang tidak ergonomis menyebabkan terjadinya Musculoskeletal Disorders (MSDs)

Kata Kunci: ergonomis; pandemi; pembelajaran daring; keluhan muskuloskeletal 


\section{INTRODUCTION}

The pandemic period forces all activities to be carried out remotely from home. Activities, including student learning, were carried out online by utilizing internet facilities. Students use laptops by utilizing internet facilities as a learning tool. ${ }^{1}$ The use of laptops, which have only been used in tracing the learning literature, is now the primary medium for learning at home. The duration of using laptops increases during online learning.

Using a laptop that is not ergonomic can cause complaints to the back, shoulders, or other organs that lead to musculoskeletal disorders. According to Riskesdas, the prevalence of MSDs disease based on the diagnosis of health workers mainly was in Bali $19.3 \%$, East Java $26.9 \%$, while the highest one was NTT $33.1 \%$. The prevalence of MSDs can occur with increasing age. At productive age, the risk of experiencing MSDs complaints is generally among students whose age range is $15-24$, namely $1.5-7 \%{ }^{2}$ Based on research conducted by Wicaksono et al., 91.7\% of architectural engineering students have experienced MSDs due to the use of laptops. Meanwhile, the results of work posture of $78.3 \%$ made changes in posture while working. It revealed that $6.7 \%$ of students used laptops $>2$ hours every day and $63.3 \%$ used laptops with a frequency of $>5$ days. ${ }^{3}$

The use of a laptop makes the space for the hands to type narrow, wrists that do not fit, the position of the elbows is not suitable, the wrong sitting position is bent, and the head is bent forward. When sitting using a laptop, the body position is an upright chest and not bending over; the laptop is placed on a table with an inappropriate table height and a chair without a backrest. ${ }^{4}$ It can lead to health problems of MSDs. If the muscles continue to receive static loads repeatedly, there will be musculoskeletal complaints in muscles, joints, tendons, intervertebral discs, peripheral nerves, and the acute to the chronic vascular system. The frequent complaints include mild to severe pain, swelling, redness, tingling, heat, soreness, numbness, muscle and joint stiffness, weakness and loss of hand coordination. ${ }^{5}$

According to some experts, several factors cause MSDs, namely occupational factors, work factors, environmental and psychosocial factors. Work factors include work posture, duration, workload, frequency, and coupling tools. Meanwhile, worker factors include age, gender, working time, years of service, exercise habits, and Body Mass Index. ${ }^{6}$

Based on the research by Sari, age is associated with musculoskeletal disorders in laundry workers with a pvalue $<0.005$. In addition, the work is done using high muscle strength and repetitive movements. It is similar to the research from Prawira revealing a relationship between age and musculoskeletal complaints in students in Bali. The complaints were primarily felt in the back and waist because they had to sit for 5-6 hours a day. ${ }^{7,8}$ A study on students of the Department of Informatics found no significant relationship between the duration of using a laptop and the musculoskeletal complaints experienced. Thus, based on the results of previous studies, researchers are interested in conducting research to identify the correlation between the position and duration of using laptops with musculoskeletal disorders in medical students during online learning.

\section{METHODS}

This research is analytic observational with a cross-sectional approach. The study has received approval from the research ethics committee in Unit Bioetika dan Humaniora Kedokteran Islam (UBHKI) Faculty of Medicine Universitas Muhammadiyah Palembang. The research was conducted on students of the Medical Study Program, Faculty of Medicine, Muhammadiyah Palembang University, who met the inclusion and exclusion criteria with a total sample of 416 respondents in February-March 2021. The inclusion criteria were active students of the medical study program and willing to participate in research with informed consent. Meanwhile, exclusion criteria included having a history of and suffering from musculoskeletal diseases such as Rheumatoid arthritis, osteoarthritis, and spinal disorders (kyphosis, lordosis, scoliosis).

Primary data collection was carried out using a questionnaire. The process of distributing questionnaires was carried out by giving questionnaires to respondents online through a google form. The research variables in the form of the duration of using the laptop and the laptop's position were determined by using a questionnaire of using the laptop and its body position. Musculoskeletal complaints were measured using a Nordic Body Map questionnaire, including scoring of complaints in the neck, shoulders, elbows, upper and (NBM) lower backs and arms, thighs, knees, hands, and feet which were categorized into 4, namely; no pain got a score of 0 , a mild pain got a score of 1 , moderate pain get a score of 2, and severe pain get a score of 3 . The level of MSDs complaints was considered non-existent if the total NBM score was less than 28 and mild if the total NBM score was 28-49. Moreover, it was moderate if the NBM score is 50-70 


\section{mutiara medika}

and severe if the NBM score is 71-111.6. The collected data were processed in univariate form with the frequency distribution and bivariate analysis using the Chi-Square test with a significance level of 0.05 .

\section{RESULT}

There were a total of 429 respondents who filled out the questionnaire and obtained 416 respondents who met the inclusion and exclusion criteria with the characteristics of the respondents as shown in Table 1.

Table 1. Subject Characteristics

\begin{tabular}{lcc}
\hline Characteristics & Frequency $(\mathbf{n}=416)$ & Percentage $(\%)$ \\
\hline Gender & & \\
Male & 87 & $20.9 \%$ \\
Female & 329 & $79.1 \%$ \\
Age & & \\
17-18 years old & 107 & $25.7 \%$ \\
19-20 years old & 259 & $62.3 \%$ \\
21-22 years old & 50 & $12.0 \%$ \\
Body Mass Index & & \\
Underweight & 21 & $5.0 \%$ \\
Normal & 366 & $88.0 \%$ \\
Overweight & 29 & $7.0 \%$ \\
\hline
\end{tabular}

Table 1 shows that the majority of respondents were females (79.1\%), with the most dominant age group of $19-20$ years old (62.3\%) and having a normal body mass index (90.4\%).

Table 2. Distribution of Respondents Based on Characteristics of Laptop Use

\begin{tabular}{lcr}
\hline Characteristics & Frequency $(\mathbf{n}=416)$ & Percentage (\%) \\
\hline Duration & & \\
Low & 24 & $5.8 \%$ \\
Moderate & 189 & $45.4 \%$ \\
High & 203 & $48.8 \%$ \\
Position & & \\
Not good & 176 & $42.3 \%$ \\
Enough & 130 & $31.3 \%$ \\
Good & 110 & $26.4 \%$ \\
\hline
\end{tabular}

Table 2 shows that most respondents, namely 203 people (48.8\%), used laptops with high duration, and most respondents, namely 176 people (42.3\%), used laptops in a not good position.

Table 3. Distribution of Respondents Based on the Complaints in Musculoskeletal Disorders

\begin{tabular}{lcccc}
\hline \multirow{2}{*}{ Body Organ } & \multicolumn{2}{c}{ With Complaints } & \multicolumn{2}{c}{ No Complaints } \\
\cline { 2 - 5 } & $\mathrm{f}$ & $\%$ & $\mathrm{f}$ & $\%$ \\
\hline Neck & 314 & 75.5 & 102 & 24.5 \\
Shoulder & 209 & 50.2 & 207 & 49.8 \\
Elbow & 62 & 14.9 & 354 & 85.1 \\
Upper Arm & 103 & 24.8 & 313 & 75.2 \\
Upper Back & 247 & 59.4 & 169 & 40.6 \\
Lower Arm & 73 & 17.6 & 343 & 82.4 \\
Lower Back & 327 & 78.7 & 89 & 21.3 \\
Wrist/Hand & 96 & 23.1 & 320 & 76.9 \\
Hip/Thight & 195 & 46.9 & 221 & 53.1 \\
Knee & 86 & 20.6 & 330 & 79.4 \\
Heel/Feet & 73 & 17.6 & 343 & 82.4
\end{tabular}

Table 3 shows that the body organs most frequently complained about were: the lower back of 327 respondents (78.7\%); neck of 314 respondents (75.5\%); upper back of 247 respondents (59.4\%); shoulders of 
209 respondents (50.2\%) and hips/thighs of 195 respondents (46.9\%). Meanwhile, the body organs with the minor complaints included the elbows, arms, wrists/hands, knees, and heels/feet.

Table 4. Distribution of Respondents Based on the Level of Complaints in Musculoskeletal Disorders

\begin{tabular}{lcccc}
\hline \multirow{2}{*}{ Body Organ } & \multicolumn{4}{c}{ Level of Complaints } \\
\cline { 2 - 5 } & No Pain & $\begin{array}{c}\text { Mild } \\
\text { Pain }\end{array}$ & $\begin{array}{c}\text { Moderate } \\
\text { Pain }\end{array}$ & $\begin{array}{c}\text { Severe } \\
\text { Pain }\end{array}$ \\
\hline Neck & 24.5 & 56.9 & 16.7 & 1.9 \\
Shoulder & 49.8 & 37.3 & 10.6 & 2.3 \\
Elbow & 85.1 & 12.5 & 2.4 & 0 \\
Upper Arm & 75.2 & 19.9 & 4.6 & 0.3 \\
Upper Back & 40.6 & 42.2 & 15.1 & 2.1 \\
Lower Arm & 82.4 & 15.5 & 1.6 & 0.5 \\
Lower Back & 21.3 & 49.1 & 25.7 & 3.9 \\
Wrist/Hand & 76.9 & 19.2 & 3.0 & 0.9 \\
Hip/Thight & 53.1 & 32.1 & 13.2 & 1.6 \\
Knee & 79.4 & 16.2 & 3.7 & 0.7 \\
Heel/Foot & 82.4 & 14.1 & 2.8 & 0.7 \\
\hline
\end{tabular}

Table 4 shows the frequency distribution of respondents based on the severity of the musculoskeletal disorders felt in each body part due to using a laptop. The mildest complaints were felt in the neck (56.9\%), while the most moderate and severe pain complaints were felt by respondents in the lower back, with a total of $25.7 \%$ and $3.9 \%$, respectively.

Table 5. Distribution of Respondents Based on the Level of Complaints in Musculoskeletal Disorders (MSDs) as Calculated by the Nordic Body Map

\begin{tabular}{lcc}
\hline Muskuloskeletal Disorders & $\begin{array}{c}\text { Frequency } \\
(\mathbf{n}-416)\end{array}$ & Percentage (\%) \\
\hline No complaint & 162 & 38.9 \\
Complaint & 254 & 61.1 \\
\hline
\end{tabular}

Table 5 shows the frequency distribution of respondents based on the presence or absence of complaints based on the calculation of the total score. If the total score is $<28$, it is categorized as no complaints. Moreover, if it is $>28$, which is included in moderate and severe complaints, it is included as the complaint category. Based on the results of the study, it was found that the majority of respondents of 254 people (61.1\%) had musculoskeletal disorders.

Table 6. Results of Bivariate Analysis of the Relationship between Duration of Use of Laptops and Musculoskeletal Disorders

\begin{tabular}{lccc}
\hline \multirow{2}{*}{ Variable } & \multicolumn{2}{c}{ Muskuloskeletal Disorders } & \multirow{2}{*}{$\mathrm{p}^{*}$} \\
\cline { 2 - 3 } & No complaint & With Complaint & \\
\hline Duration & 147 & 56 & 0.652 \\
High & 99 & 90 & \\
Moderate & 8 & 16 & \\
Low & & & \\
Position & 139 & 37 & 0.002 \\
Poor & 67 & 63 & \\
Moderate & 48 & 62 & \\
Good & & & \\
\hline
\end{tabular}

* Chi-square analysis

Table 6 shows that the respondents with a high duration of laptop use had musculoskeletal disorders. Statistically, the results showed a $p$-value of 0.652 ( $p>0.05$ ), indicating that there was no significant relationship between the duration of laptop use and musculoskeletal disorders. In the case of respondents with a poor laptop usage position, the majority had musculoskeletal disorders, and statistically, 
the results showed a p-value of $0.002(p<0.05)$, indicating that there was a significant relationship between the position of laptop use and musculoskeletal disorders.

\section{DISCUSSION}

Many factors influence musculoskeletal complaints, including unnatural work attitude, long and static sitting, repetitive activities, and individual factors such as age, gender, body size, and body organization. Noor's research showed a correlation between age and years of service with musculoskeletal complaints in brick craftsmen. Putri also mentioned a relationship between age, work period, and work posture with complaints of musculoskeletal disorders. Furthermore, Fathoni et al. (2009) also stated there was a relationship between age and length of work with Low Back Pain for Nurses in Purbalingga District hospital. 9-12

Based on the research results, it was found that the duration of student use of laptops was high during the pandemic. In addition to making lecture assignments, laptops are a routine activity in supporting the learning process online. Moreover, the study also revealed that the musculoskeletal disorders experienced by students of the Faculty of Medicine, Muhammadiyah University of Palembang, were not related to the duration of using a laptop. The results of this study are in line with research conducted by Wijaya, Kurniasari, Lahdji, and Ali on students of the Department of Informatics, Yogyakarta State University, denoting that there was no significant relationship between the duration of using a laptop and the musculoskeletal complaints experienced. Besides, Lahdji's research also found no relationship between the length of work and Musculoskeletal Disorders in Laundry workers. Ali's research found that there was no significant relationship between the duration of using a laptop and the health complaints that were felt due to the use of a laptop. 13-15 $^{-15}$

In addition, Tjahayuningtyas's research (2019) showed work period has a relationship with the musculoskeletal disorder ( $\mathrm{p}$ 0.019). ${ }^{16}$ The maximum duration of each laptop use is two hours. In theory, a longer duration can lead to greater exertion, abnormal posture, and static posture. The duration of work for a person determines the level of work efficiency and productivity. ${ }^{5,6}$

Based on the study results, the musculoskeletal disorders experienced by students of the Faculty of Medicine, Muhammadiyah University of Palembang were related to the position of using a laptop. The results of this study are in line with what was done by Ali to the employees of the Subang District Health Office. ${ }^{14}$ It was found a significant relationship between body position when using a laptop and perceived health complaints. Furthermore, the results of this study are also in line with the results of research by Wicaksono et al. on students of the Faculty of Engineering, Department of Architecture, Diponegoro University, who found a relationship between work posture and musculoskeletal complaints with a p-value of $0.030 .{ }^{3}$

Besides, complaints on the lower and upper back are common complaints. It can occur due to bad sitting posture, such as an unstable body position, forming an angle of $90-100^{\circ}$. In addition, it can also be caused by sitting without leaning on a chair, and the respondent rarely stretches the two parts of the body. ${ }^{6}$

Many respondents also felt complaints about the neck. The position of the head when using the laptop is looking down or looking up, which also causes the muscles to become tense quickly. This bowing position can be caused by the low table position so that it is not under the anthropometry of the body. The position with the high table also causes the neck to be raised more so that it is not under the anthropometry of the body. ${ }^{7}$ In addition, neck pain was also caused by the respondent not stretching his body every two hours for 15 minutes while using a laptop. These results are in line with Situmorang's research where there is a relationship between overall posture and use of the neck with complaints of Neck Pain in education personnel from the Faculty of Public Health, Diponegoro University. ${ }^{5}$

Furthermore, there are also many complaints about the shoulder. It can happen as the respondent does not lean on the chair when using the laptop. The position of the table is too high so that the elbows do not form 900 and do not stretch the body, causing the shoulder muscles to become tense and sore. ${ }^{18}$

The subsequent most common complaint is on the hips/thighs. It can occur since the position of the respondent's feet when using the laptop is not under ergonomic principles such as hanging one thigh to another, hanging legs (not tread on the floor), folding the legs, both on the floor and in the chair while sitting. These positions cause the unsmooth flow of blood to the lower body. Thus, to prevent a static body position, stretching the body is necessary. It functions to improve blood circulation in the body so that the oxygen supply throughout the body is fulfilled. ${ }^{19,20}$

In Dinar's research, there was a significant relationship between the ergonomics of the chairs used when working and musculoskeletal complaints, namely the length of the chair and buttocks-popliteal ( $p$ 0.04). In line with the research, Jalajuwita and Indriyati's research in 2015 also found a significant relationship between the work position and musculoskeletal complaints in welding workers and showed a moderate level 
of correlation. Daika's research also concluded that the working postures have a mild correlation $(r$ 0.407) with musculoskeletal disorder complaints. ${ }^{21-23}$

Based on the explanation above, respondents who used laptops for more than six hours and in improper positions had the possibility of experiencing moderate to severe musculoskeletal complaints. In static muscle work, blood vessels are compressed by the increased pressure in the muscles due to contraction, causing blood circulation in the muscles to be disturbed. In dynamic muscle work, it increases 10-20 times of the static muscle work. Muscles need energy when they contract. The energy comes from the breakdown of ATP (Adenosine Triphosphate) molecules into ADP (Adenosine Diphosphate) in the muscles. If the contraction continues, energy is taken from glucose compounds due to the obstruction of blood circulation that channels oxygen, food materials, and metabolic waste. Clucose will undergo glycolysis into pyruvic acid and ATP, which will be used for muscle contraction. Pyruvic acid in muscle cells can be converted into lactic acid. Lactic acid built up in muscles can cause soreness, pain, or fatigue. ${ }^{6,24}$ In terms of limitation of this study, there is no measurement of the ergonomics of the chairs used so that it cannot simultaneously assess the correlation of chair ergonomics and musculoskeletal disorders.

\section{CONCLUSION}

Based on the result of this study, it is concluded that there was no correlation between the duration of using laptops during online learning and musculoskeletal disorders. However, there was a correlation between the position of using laptops during online learning and musculoskeletal disorders.

\section{CONFLICT OF INTEREST}

There is no conflict of interest.

\section{REFERENCES}

1. Desy E. 2020. Efektifitas Pembelajaran Melalui Metode Daring (Online) dalam Masa Darurat Covid-19. diakses tanggal 16 Desember 2020 di www.stit-alkifayahriau.ac.id

2. Balitbang Kemenkes RI. 2013. Riset Kesehatan Dasar (RISKESDAS). Jakarta: Balitbang Kemenkes RI.. diakses tanggal 18 Januari 2021 di www.litbang.kemkes.go.id

3. Wicaksono RE, Suroto, Baju W. Hubungan Postur, Durasi dan Frekuensi Kerja dengan Keluhan Muskuloskeletal akibat Penggunaan Laptop pada Mahasiswa Fakultas Teknik Jurusan Arsitektur Universitas Diponegoro. Jurnal Kesehatan Masyarakat. Juli 2016; 4(3): 568-80.

4. Wahyuningtyas S, Laili I, Solihatul M. Hubungan antara Perilaku Penggunaan Laptop dengan Keluhan Muskuloskeletal Disorder (MSDS) pada Mahasiswa Teknik Informatika. Prosiding $1^{\text {st }}$ Seminar Nasional Arah Kebijakan dan Optimalisasi Tenaga Kesehatan Menghadapi Revolusi Industri 4.0. Fakultas Ilmu Kesehatan Universitas Muhammadiyah Ponorogo. 2019. 196-206.

5. Situmorang CK, Baju W, Ida W. Hubungan antara Durasi dan Postur Tubuh Penggunaan Komputer terhadap Keluhan Neck Pain pada Tenaga Kependidikan Fakultas Kesehatan Masyarakat Universitas Diponegoro. Jurnal Kesehatan Masyarakat. September 2020; 8(5); 672-8.

6. Tarwaka. Ergonomi untuk Keselamatan, Kesehatan Kerja dan Produktivitas. Surakarta: UNIBA Press; 2014.

7. Sari EN. Hubungan antara Umur dan Masa Kerja dengan Keluhan Musculoskeletal Disorders (MSDs) pada Pekerja Laundry. Jurnal Kedokteran dan Kesehatan. 2017; 13(2): 183-93.

8. Prawira. Faktor yang Berhubungan terhadap Keluhan Musculoskeletal pada Mahasiswa Universitas Udayana. Journal of Industrial Hygiene and Occup Health. 2017; 1(2):101-18. http://dx.doi.org/10.21111/jihoh.v1i1.748

9. Kuswara. Ergonomi dan K3 (Kesehatan dan Keselamatan Kerja). Bandung; Remaja Rosdakarya; 2014

10. Noor IH, Zairin NH, Ratna S. The Correlation between Age, Tenure and Height with Musculoskeletal Disorders Complaint (Observational Study among Brick Craftsman in Lok Buntar Village Sungai Tabuk district). Proceedings International Seminar and Workshop on Public Health Action "Building Healthy Community". Faculty of Health Sciences Dian Nuswantoro University. Dec 2015. 167-75.

11. Putri BA. The Correlation between Age, Years of Service and Working Postures and the Complaints of Muskuloskeletal Disorders. The Indon Journal of Occupational Safety and Health 2019 August; 8(2);187-96. http://dx.doi.org/10.20473/ijosh.v8i2.2019.187-196

12. Fathoni, H., Handoyo \& Swasti K.G. Hubungan Sikap dan Posisi Kerja dengan Low Back Pain pada Perawat di RSUD Purbalingga. Jurnal Keperawatan Soedirman. 2009; 4(3): 131-39. http://dx.doi.org/10.20884/1.jks.2009.4.3.242 
13. Wijaya AT, Darwita RR, dan Bahar A. The Relation between Risk Factors and Musculoskeletal Impairment in Dental Students; a Preliminary Study. Journal of Dentistry Indonesia. 2011;18 (2); 33-7. https://doi.org/10.14693/jdi.v18i2.61

14. Kurniasari ND, Siti HI, Lilik I. Hubungan Durasi, Frekuensi dan Posisi Penggunaan serta Ukuran Laptop dengan Keluhan Muskuloskletal pada Mahasiswa jurusan Pendidikan Teknik Informatika di Universitas Negeri Yogyakarta. Sanitasi, Jurnal Kesehatan Lingkungan. 2015 Mei; 6(4): 165-75.

15. Lahdji A, Hema DA. Effects of Age, Work Period and Work Duration on Musculoskeletal Disorders in Laundry Workers. Advances in Health Sciences Vol 24. $5^{\text {th }}$ University Ahmad Dahlan Public Health Conference UPHEC. 2019. https://doi.org/10.2991/ahsr.k.200311.034

16. Muslimin A. Hubungan Perilaku Penggunaan Laptop dengan Keluhan Kesehatan akibat Penggunaan Laptop. Jurnal Kesehatan. 2018; 9(1): 26-33. https://doi.org/10.38165/jk.v9i1.75

17. Tjahayuningtyas. Faktor yang Mempengaruhi Keluhan Muskuloskeletal Disorders (MSDs) pada Pekerja Informal. The Indonesian Jour of Occup Safety and Health. 2019; 8(1): 1-10. http://dx.doi.org/10.20473/ijosh.v8i1.2019.1-10

18. Agusdianti LN. Sudirman PL, Muliarta IM. 2017. Edukasi Ergonomi Menurunkan Keluhan Muskuloskeletal dan Memperbaiki Konsistensi Postur Tubuh pada Mahasiswa PSPDG Universitas Udayana. Bali Dental Journal 2017 Juli-Des; 1(2): 47-53.

19. Ozaras N. Differential Diagnosis in Upper Back Pain. Journal of Rheum Dis and Treat 2015 February; 1(1); $46-$ 63.

20. Siangsukon C 2013. Relationship between Low Back Pain and Sleep Quality. Novel Physiotherapis. vol 3(4): July 2020. https://doi.org/10.4172/2165-7025.1000168

21. Dinar A. Analysis of Ergonomic Risk Factors in Relation Musculoskeletal Disorders Symptom in Office Workers [thesis]. Depok; Fakultas Kesehatan Masyarakat Universitas Indonesia; 2018. https://doi.org/10.18502/kls.v4i5.2536

22. Jalajuwita RN, Indriati P. Hubungan Posisi Kerja dengan Keluhan Musculoskeletal pada Unit Pengelasan PT. $\mathrm{X}$ Bekasi. The Indonesian Journal of Occup Safety and Health. 2015 Jan-Jun; 4(1): 33-42. http://dx.doi.org/10.20473/ijosh.v4i1.2015.33-42

23. Daika Nefri. Correlation between Working Posture and Musculoskeletal Disorder Complaints Suffered by the Fishermen in Tanjung Village, Sumenep District. The Indonesian Journal of Occup Safety and Health. 2019 Dec ;8(3): 258-64. http://dx.doi.org/10.20473/ijosh.v8i3.2019.258-264

24. Hossain MD. Prevalance of Work Related Muskuloskeletal Disorders (Wmsds) and Ergonomic Risk Assessment among Readymade Garment Workers of Bangladesh. Grant School of Public Health. BRAC University. Bangladesh. 2018 https://doi.org/10.1371/journal.pone.0200122 